\title{
Impact of Forensic Accounting on University Financial System in Nigeria
}

\author{
Osho, Augustine E.(PhD) \\ Department of Accounting, Achievers University, Owo, Nigeria
}

Doi: 10.19044/esj.2017.v13n31p571 URL:http://dx.doi.org/10.19044/esj.2017.v13n31p571

\begin{abstract}
This study examines the effect of forensic accounting on University financial system in Nigeria. The University cannot run without finance which required proper management on the side of the University management so as to avoid mismanagement of fund. Two theories that are of interest to this study Profession Theory and Relative Size Factor Theory are reviewed alongside with the literature reviewed accordingly. The study used ex-post factor research design using data analysis of financial information extracted from audited Financial Statement for the years 2005 to 2014 which is used to examine how an independent variable, present prior to the study, affects a dependent variable. In order to arrive at the testable conclusion, stratified and purposive random sampling techniques were adopted. Simple and multiple regression analysis were used in this research work with the model findings which revealed that University Financial System in Nigeria is significantly affected by the combine effect of all the exogenous variables. It is recommended that University management and the stakeholders should utilize the findings of the study in taking decisions with respect to efficient management of all the components of Forensic Accounting in order to grow their University.
\end{abstract}

Keywords: Financial Reporting, Financial Statement, Financial System, Forensic Accounting, University Financial System, University Sytem.

\subsection{Introduction}

In spite of the rapidly growing demand for forensic accounting globally, this concept is still confined mainly to economies of developed countries with simplified application in emerging economies (Somoye and Osho, 2017). Forensic accounting is not a new field because evidence showed that the profession has been in existence a long time ago when the profession was not yet being called forensic accounting. Forensic accounting is a new and rapidly growing area of accounting in Nigeria and is concerned 
with the detection and prevention of financial fraud and white collar or economic crimes. It was however gathered that forensic accounting is a new trend in Nigeria Universities, which is yet to gain ground in developing economies, hence University accountants lack the technical know-how on forensic issues in the University accounting system.

According to Somoye and Osho (2017), University cannot do without appropriate finance either through internally generated revenue or receiving or government subvention which will require appropriate management in term of spending within the global village of the institution and the management will be laid upon a competent and qualified chartered accountant that will integrate accounting, auditing and investigate skill. Bologna and Linquist (1995) defined forensic accounting as the application of financial skills and investigative mentality to unre-solved issues, conducted within the context of the rules of evidence. Forensic accounting involves the application of accounting and audition, financial and investigates skills, to unsettled issues, conducted within the context of the rules of evidence (see. Arokiasamy and Cristal-Lee, 2009; Ozkul and Pamukc, 2012). Forensic accounting is practices where by accountants use their business skills to investigate fraud, embezzlement of funds, theft of assets, or perhaps find evidence of hidden assets in divorce cases. Therefore, forensic accounting can be seen as an aspect of accounting that is suitable for legal review and offering the highest level of assurance (Apostolou, Hassell, and Webber, 2000).

The University Financial System (UFS) is the set of implemented procedures that track the financial activities of the institution. It encompasses financial accounting, research grant accounting and financial and management reporting.

Forensic accountants have played an increasingly important role in the litigation and other legal disputes fomented by these recent frauds and failures in companies but none have been done in the area of University financial system. The fact is that none has been written in this area. Based on the problem stated above, this study focuses to proffer solution to fill the gap in literature and increase the frontiers of knowledge with respect to the impact of forensic accounting on University financial system in Nigeria.

The nexus between forensic accounting and it impact on the university financial system is worthy of investigation. This research would therefore empirically seek answers to the impact of forensic accounting on University financial system in Nigeria.

\subsection{Literature Review}

The concept of Forensic accounting or financial forensic is the specialty practice area of accounting that describes engagements that result 
from actual or anticipated disputes or litigation. Forensic accountants also referred to as forensic auditors or investigate auditors, often have to give expert evidence at the eventual trial. Forensic accountants analyze, interpret and summarize complex financial and business matters. They can be employed by Universities, insurance companies, banks, police forces, government agencies or public accounting firms. Forensic accountants compile financial evidence, develop computer applications to manage the information collected and communicate their findings in the form of reports or presentations.

We have seen auditors performing fraud investigation, expert witnessing,, due diligence; etc. Probably as a new era, and professional advancement unfolding various strengths and opportunities and also embracing various perspectives, there is none gainsaying that accounting is also in this same trend. Forensic accounting, also called investigative accounting or fraud audit, is a merger of forensic science and accounting. According to Crumbley (2003) forensic science "may be defined as application of the laws of nature to the laws of man". He refers to forensic scientists as examiners and interpreters of evidence and facts in legal cases that also offers expert opinions regarding their findings in court of law. The science in question here is accounting science, meaning that the examination and interpretation will be of economic information.

Forensic accounting utilizes accounting auditing and investigative skills to conduct an examination into a company's financial statement. Thus, forensic accounting provides an accounting analysis suitable for court. Forensic accountants are trained to look beyond the numbers and deals with the business reality of a situation. They are frequently used in fraud cases. This is affirmed by Zysman (2004), forensic accounting utilizes accounting, auditing and investigative skills, Hao (2010) believes that the forensic accounting is the result of the integration between the legal framework and the accounting framework.

In view of Howard and Sheetz (2006), forensic accounting is the process of interpreting, summarizing and presenting complex financial issues clearly, succinctly and factually in a court of law as an expert. It concerns with the use of accounting discipline to help determine issues of facts in business litigation (Okunbor and Obaretin, 2010).

Joshi (2003) defined Forensic Accounting as the application of specialized knowledge and specific skill to stumble up on the evidence of economic transactions. Zysman (2001) believe that Forensic account as the integration of accounting, auditing, and investigative skills. Simply put, forensic accounting is accounting that is suitable for legal review offering the highest level of assurance and including the now generally accepted connotation of having been arrived at in a scientific fashion (Crumbley, 
2006). Coenen (2005) stated that forensic accounting involves the application of accounting concepts and techniques to legal problem. It demands reporting, where the accountability of the fraud is established and the report is considered as evidence in the court of law or in the administrative proceeding. It provides an accounting analysis that is suitable to the court, which will form the basis of discussion, debate and ultimately dispute resolution (Zysman, 2001).

Gray (2008) reported that the forensic accountants investigation include identification fraud. Bologna and Lindquist (1995) as quoted by Chariri (2009) stated that as an investigator, a forensic accountant can be seen as those who are specialists in fraud detection, and particularly in documenting exactly the kind of evidence required for successful criminal prosecution, able to Work in complex regulatory and litigation environment, and with reasonable accuracy, can reconstruct missing, destroyed or deceptive accounting records.

\subsection{Concept of University Financial System}

The University Financial System (UFS) encompasses financial accounting, research grant accounting and financial and management reporting.

According to General Accepted Accounting Principles (GAAP), financial accounting is a specialized branch of accounting that keeps track of a company's financial transactions. Using standardized guidelines, the transactions are recorded, summarized, and presented in a financial report or financial statement such as an income statement or a statement of financial position. At the heart of financial accounting is the system known as double entry book keeping (or "double entry accounting").

According to ACCA (2016), Research grants are grants that is of fund research which are made available by various institutions to help fund research efforts made by individuals, universities, and other groups. Research can encompass many subjects, such as literature, medicine, and the environment. The grants can vary greatly in the amount they offer, from small grant awards, to full, multi-year fellowship. Research grants can be applied to research that is already taking place or pave the way for completely new research in a field. The money public or private agencies put towards research provide a significant boost to groups working in a certain field. The money can be unrestricted or allow only for a certain amount to cover living expenses .... It all depends on the guidelines of the grant. In addition to this, financial reporting occurs through the use of financial statements.

Financial accounting results in the determination of net income at the bottom of the income statement. Assets, liabilities and equity accounts are 
reported on the statement of financial position. The statement of financial position utilizes financial accounting to report ownership of the future economic benefits of the company. According to Osborne (2015), management reporting requires creative thinking. The work of a management accountant should answer the question of what operational factors are driving the business's performance. Unlike financial reporting, there is no prescribed rules and methods when it comes to management reporting. The goal of the discipline is to identify useful measures, or key performance indicators, that will give upper management an accurate picture of how the business is doing operationally and industry but they should help to explain the company's financial performance. Since there are no hard and fast rules when it comes to what ratios or measures to use in this type of reporting, a management accountant must have the ability to understand business process, break down operational steps and think creatively to come up with appropriate performance indicators.

\subsection{Areas and Development for the University Financial System in Nigeria}

The current areas of support and development for the University Financial System in Nigeria comprises core financial system, procurement, research financial administration, resource management, oracle system administration and reporting. Such system must be able to provide consistent, standardized information for the University Forensic Accountant, Internal and External Auditors, program managers, financial managers, agency executives, and oversight generations and they must meet International Federation of Accountants (IFAC), International Financial Reporting Standards (IFRS), regulations and standards. 


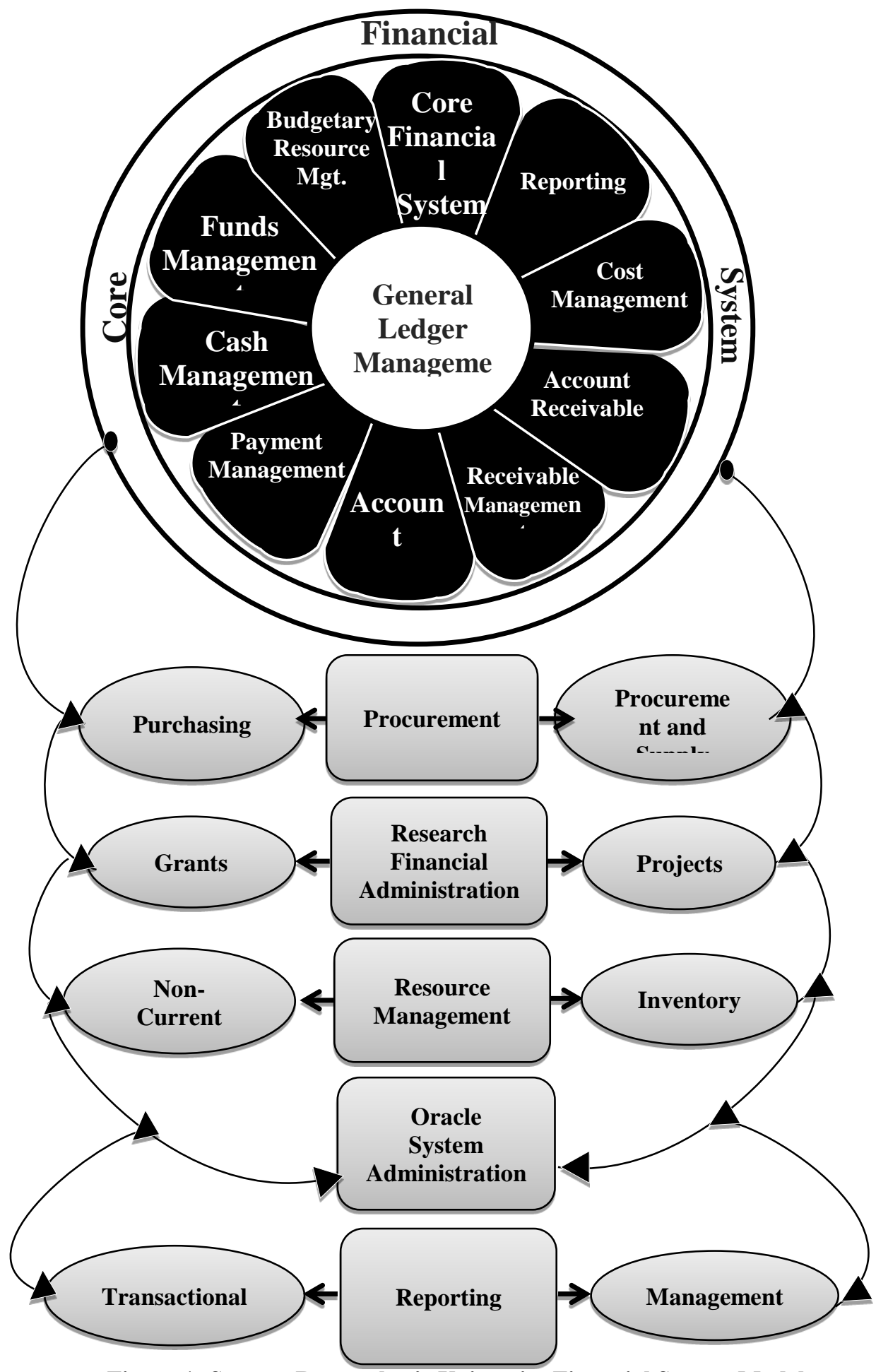

Figure 1: Source: Researcher's University Financial System Model 
The model (Figure 1) above provides an architectural view of the current areas of support and development for the University Financial System model. The model describes the basic elements of a model for integrating Forensic Accounting with the University Financial Systems in the Federal Universities, State Universities and Private Universities. It provides a foundation for all the systems. The model is divided into six parts which is explained sequentially with their derived model too.

\subsubsection{Core Financial System}

A Core Financial System may perform all financial functions, including core financials system management, general ledger management, payment management, account payable, receivable management, account receivable, cost management and reporting.

- Core Financial System Management: According to Somoye and Osho 2017 cited in GAO Financial Management Series, 2005, this consists of all the processes necessary to maintain the financial system in a manner that is consistent with established financial management laws, regulations and policy. This element sets the frameworks for all other core financial system functions.

- General Ledger Management: This is where an entity records all the information for its various income streams and expenses types into separate accounts, so that all the credits and debits relating to that particular type of transaction can be entered in one place and kept balanced. According to Moran (2017), is the financial reports that are produced from the campus general ledger are used by a wide variety of individuals and organization to assess the campus' financial position and how well it has spent its funds.

- Budgetary Resource Management: The (BRM) group/unit/section/ division provides strategic financial planning and analysis for the Vice Chancellor and directors of an institution for planning and control within the University System (Somoye and Osho, 2017).

- Funds Management: It is the systematic process of operating, deploying, maintain, disposing and upgrading assets in the most cost-efficient and profit yielding way possible. The entity is responsible for establishing a system for ensuring that it does not obligate or disburse funds in excess of those appropriated or authorized (Somoye and Osho, 2017 cited in GAO Financial Management Series, 2005).

- Cash Management: Cash management is a way that an organization will manage all aspects of the financial end of the business, such as the collection of revenue as well as the investing of the organization's cash and other assets. This helps a business to stay 
afloat financially. According to Business Advameg (2013) and Small Business Note (2013), Cash management refers to a broad area of finance involving the collection, handling, and usage of cash. It involves assessing market liquidity, cash flow, and investments.

- Payment Management: Payment management provides appropriate control over all payments made on behalf of the agency (GAO Financial Management Series, 2005). Universities initiate payments to: vendors in accordance with contracts, purchase orders and other obligating documents, state governments under a variety of programs, employees for salaries and expenses reimbursements, other Federal agencies for reimbursable work performed; individual citizens receiving Federal benefits, recipients of Federal loans and make payments for other reasons.

- Accounts Payable: This is the aggregate amount of an entity's shortterm obligations to pay suppliers for products and services which the entity purchased on credit. If accounts payable are not paid within the payment terms agreed to with the supplier, the payables are considered to be in default, which may trigger a penalty or interest payment, or the revocation or curtailment of additional credit from the supplier.

- Receivable Management: This is the payment supported by the activities associated with recognizing and recording debts due to the government, performing follow-up actions to collect on these debts, and recording agency cash receipts. A receivable is recognized when an agency establishes a claim to cash or other against other entities (Somoye and Osho cited in GAO Financial Management Series, 2005).

- Accounts Receivable: This is a short-term amount due from buyers to a seller who have purchased goods or services from the seller or credit. Accounts receivable is listed as a current asset on the seller's statement of financial position (Somoye and Osho, 2017 cited in Accounting Dictionary (2016)

- Cost Management: According to Georgas \& Vallance (1986), Cost Management is one of the primary functions of Project Managers. When integrated with the scope/quality of the project and time management, these three functions form the core of Project Management. Therefore, it is the process of planning and controlling the budget of a business. Cost management is a form of management accounting that allows a business to predict impending expenditures to help reduce the chance of going over budget. 
- Reporting: The University Core Financial system must be able to provide timely and useful financial information to support: management's fiduciary role; budget formulation and execution functions; fiscal management of program delivery and program decision making; and internal and external reporting requirements (Somoye and Osho, 2017).

\subsubsection{Procurement}

All procurement requirements begin with the perception of a need. The need to cross a body of water could create a requirement to build a bridge, a ferry, or other transportation systems. The major elements within the Procurement include purchasing and procurement and supply.

- Purchasing: Purchasing refers to a business or organization attempting to acquire goods or services to accomplish the goals of its enterprise. Though there are several organizations that attempt to set standards in the purchasing process, processes can vary greatly between organizations.

- Procurement and Supply:

According to Chartered Institute of Procurement and Supply (2016), Procurement and supply management involves buying then goods and services that enable an organization to operate.

\subsubsection{Research Financial Administration}

This is the process whereby the Research Finance Office provides support to the financial administration of University research projects at all stages throughout the Research Project Lifecycle. The major elements within the Procurement include grants and projects.

- Grants: Grants are non-repayable funds or products disbursed by one party (grant makers), often a government department, corporation, foundation or trust, to a recipient, often (but not always) a nonprofit entity, educational institution, business or an individual.

- Projects: In a contemporary business and science, a project is a collaborative enterprise, involving research or design that is carefully planned to achieve a particular aim.

\subsubsection{Resource Management}

This is the process of using company's resources in the most efficient way possible. These resources can include tangible resources such as goods and equipment, financial resources, and labour resource such as employees. The major elements within the Resource Management include noncurrent assets and inventory. 
- Non-Current Assets: A noncurrent asset is an asset that is not likely to turn to unrestricted cash within one year of the statement of financial position date. (This assumes that the company has an operating cycle of less than one year). A noncurrent asset is also referred to as a long term assets (ACCA, 2016).

- Inventory: This refers to as the goods and materials that a business holds for the ultimate purpose of resale (or repair).

\subsubsection{Oracle System Administration}

The University uses the Oracle e-Business suite as its main financial system which is owned by the Finance Division who provides functional support and development. University Information Services (UIS) support consists of the provision of technical support via hardware and operating system, database and in-house software development teams. The University Financial System (UFS) Software development technical team provides bespoke solutions to enhance Oracle Applications to reflects complex and varies business needs of the University Schools and Departments. This includes back end and front end custom solutions as well as a large number of reports.

\subsubsection{Reporting}

Reporting is a fundamental part of the larger movement towards improved business intelligence and knowledge management. The major elements within the reporting include transactional and management.

- Transactional: This is a consolidated point of reference to help firms understand and comply with their transaction reporting obligations. Therefore, Transaction reporting are often used by Assets managers that need to report transaction intraday or end of day to their clients, enabling their clients to replicate the mandate in their own portfolio management system.

- Management: Management reporting is a complex, multistage activity which takes place in the context of other business processes and makes use of the multiple information systems that may have been provided for other purposes - general documentation, project management, financial control, email communication and business presentation (Management Reporting System 2001).

\subsection{Theoretical Review}

Two theories are of interest to this study viz: Profession Theory and Relative Size Factor (RSF) Theory. These theories would help in analyzing the impact of forensic accounting on University Financial System in Nigeria, which is presented below. 


\subsubsection{Profession Theory}

The Profession Theory provides an analytical lens with which to understand the characteristics, attributes and structures of the forensic accounting profession in University financial system. Therefore, the theory of Profession is described as the power and reputation granted by society to the profession in terms of protecting public interest where professional acquire a body of knowledge, which is connected to the major needs and values of the social and accounting system (Pollock and Amernic,1981). Professionals are expected to commit their services to the interest of the public rather than the interests of their clients or self-interest (Pollock and Amernic, 1981). Therefore, accounting professionals are regarded as a mechanism to protect public interest as they are required to be act above and beyond material incentives (Larson, 1977). In the context of this study, the Theory of Profession provides a useful framework for identifying the functions and attributes of the professions. (Canning and O'Dwyer, 2001), which is consistent with the necessary requirements and qualifications to work in the field of forensic accountancy.

\subsubsection{Relative Size Factor (RSF) Theory}

According to Manas (2014), relative size factor theory shows all unusual fluctuations, which may be arise from fraud or genuine errors. RSF is measured as the ratio of the largest number to the second largest number of the given set. In practice there exist certain limits (e.g financial) for each entity such as vendor, customer, employee, etc. These limits may be defined or analyzed from the available data - if not defined. If there is any stray instance of that is way beyond the normal range, then there is a need to examine further into it. It helps in better discovery of anomalies or outliners. In records that fall outside the prescribed range are suspected of errors or fraud. These records or fields need to relate to other variables or factors in order to locate the relationship, thus establishing the truth.

\subsection{Methodology}

The study was anchored under the impact of forensic accounting on University financial system in Nigeria. The study adopted Profession Theory and Relative Size Factor (RSF) Theory.

This study used ex-post facto research design which also known as after-the-effect research is using data analyses of financial information extracted from the University Financial Statements for the years 2005 to 2014. Descriptive and inferential statistics are used to analyze the results and findings from the data which is presented in tables. This enables the researcher to explain the physical attributes of the data collected while the 
hypothesis is tested at $5 \%$ significance level by means of both t-statistics and f-statistics.

\subsection{Test of Hypothesis}

Table 4.1 Forensic Accounting does not have any significant impact on University Financial System in Nigeria.

\begin{tabular}{|c|c|c|c|c|}
\hline Variables & \multicolumn{4}{|c|}{ MODELS } \\
\hline & Coefficient & Std. Error & t-Statistic & Prob. \\
\hline C & 962703.8 & 590235.1 & 1.631051 & 0.3501 \\
\hline CFS & 0.284611 & 1.801498 & 0.21492 & 1.7315 \\
\hline P & -174.2060 & 602.5624 & -0.289109 & 0.8208 \\
\hline RFA & -0.003407 & 0.159685 & -0.021336 & 0.9864 \\
\hline RM & -0.447663 & 1.063689 & -0.420859 & 0.7464 \\
\hline R-squared & \multicolumn{5}{|c|}{0.989475} \\
\hline Adj. R-squared & \multicolumn{5}{|c|}{0.915798} \\
\hline F-Statistics & \multicolumn{5}{|c|}{0.207176} \\
\hline Prob. (F-Stat) & \multicolumn{5}{|c}{} \\
\hline Observation & \multicolumn{5}{|c|}{} \\
\hline
\end{tabular}

Dependent Variable: UFSN

\section{*Significance at $\mathbf{5 \%}$}

Source: Researcher's E-view Regression Analysis Output, 2016

\section{The Model and A priori expectation}

A priori expectation: $\alpha>0 ; \beta>0$

Functional Relationship:

$$
\left.\mathrm{UFSN}=\alpha_{1}+\beta_{1} \mathrm{CFS}+\beta_{2} \mathrm{P}+\beta_{3} \mathrm{RFA}+\beta_{4} \mathrm{RM}\right)+\mu_{1}
$$

\section{Estimated Model:}

From output statistics: UFSN $=962703.8+0.284611 \mathrm{CFS}-$

Where:

$$
\begin{aligned}
& 174.2060 \mathrm{P}+-0.003407 \mathrm{RFA}+-0.447663 \mathrm{RM} \\
& +\mu_{5}
\end{aligned}
$$

UFSN = University Financial System in Nigeria

$\mathrm{CFS}=$ Core Financial System

$\mathrm{P}=\quad$ Procurement

$\mathrm{RFA}=$ Research Financial Administration

$\mathrm{RM}=$ Resource Management

$\alpha_{1}=$ Intercept/autonomous variable. It depicts the degree of the influence of forensic accounting without the existence of University Financial System in Nigeria.

$\beta_{1-4}=$ Coefficient of forensic accounting. It is a measure of the need for University Financial System in Nigeria using net working capital component (NWC) 
$\mu_{1}=$ Random variable. It is included in the model to accommodate the effect of other determinants of forensic accounting that are not included in the model

\subsection{Unit Root Tests}

Tables 4.2 summarize the results of the unit root tests for this study using Augmented Dickey Fuller (ADF) method. We start our presentation with ADF tests as presented below:

Table 4.2: Augmented Dickey Fuller (ADF) Unit Root Test Results

\begin{tabular}{|c|c|c|c|c|c|c|c|c|}
\hline Variable & \multicolumn{3}{|c|}{ @ Levels } & \multicolumn{3}{c|}{$\mathbf{1}^{\text {st }}$ Difference } & $\begin{array}{c}\text { Level of } \\
\text { Integrat. }\end{array}$ & Rmk \\
\hline & $\begin{array}{c}\text { ADF- } \\
\text { Test }\end{array}$ & $\begin{array}{c}\mathbf{5 \%} \\
\text { C.V. }\end{array}$ & $\begin{array}{c}\mathbf{1 \%} \\
\text { C.V. }\end{array}$ & $\begin{array}{c}\text { ADF- } \\
\text { Test }\end{array}$ & $\begin{array}{c}\mathbf{5 \%} \\
\text { C.V. }\end{array}$ & $\begin{array}{c}\mathbf{1 \%} \\
\text { C.V. }\end{array}$ & & \\
\hline NWC & -1.56 & -3.32 & -4.58 & -4.86 & -3.32 & -4.58 & $\mathrm{I}(1)$ & $\mathrm{S}$ \\
\hline LC & -3.11 & -3.26 & -4.42 & - & - & - & $\mathrm{I}(0)$ & $\mathrm{S}$ \\
\hline NOR & -1.09 & -3.26 & -4.42 & -4.03 & -3.40 & -4.80 & $\mathrm{I}(1)$ & $\mathrm{S}$ \\
\hline CNA & -1.55 & -3.26 & -4.42 & -4.86 & -3.32 & -4.58 & $\mathrm{I}(1)$ & $\mathrm{S}$ \\
\hline ROI & -3.61 & -3.26 & -4.42 & - & - & - & $\mathrm{I}(0)$ & $\mathrm{S}$ \\
\hline RFA & -049 & -3.32 & -4.58 & -5.28 & -3.32 & -4.58 & $\mathrm{I}(1)$ & $\mathrm{S}$ \\
\hline RM & -3.11 & -3.26 & -4.42 & -5.53 & -3.32 & -4.58 & $\mathrm{I}(1)$ & $\mathrm{S}$ \\
\hline
\end{tabular}

Notes: RMK = Remark; S = Stationary

Source: Researcher's Regression Output (2016) using E-views 9.2

The result shown in Table 4.2 above examines the statistical properties of all the variables in the research model. The null hypothesis here is that there is a unit root in each series. That is, each variable is nonstationary. The decision rule of thumb is that the null hypothesis should be rejected if the ADF statistic is lesser than the critical value at a chosen level of significance. Accordingly, the ADF result in Table 4.2 indicates that all the variables are non-stationary at levels $\mathrm{I}(0)$ expect liquidity coverage (LC) and return on investment (ROI) that is stationary at level while all other variables are stationary in their first difference I(1). This is because the critical values are less than ADF statistics at both $1 \%$ and 5\% levels of significance in the first difference. This leads to non-rejection of the null hypothesis at levels excluding (LC) and (ROI), but the null hypothesis is rejected at the first difference for NWC, NOR, CNA, RFA and RM. Hence, the series are all integrated of order one $\mathrm{I}(1)$.

\subsection{Autoregressive Distributed Lag (ARDL) Bound Tests Results}

A co-integration test was carried out for both models using the bound tests developed by Pesaran, Shin and Smith (2001), the result is shown in table 4.3 (a) and 4.3 (b) for model I and II respectively. 
Table 4.3(a): Model (I) NWC Bounds Test Results for Co-integration ARDL Bounds Test

Null Hypothesis: No Long-run Relationship Exist

\begin{tabular}{|c|c|c|}
\hline Test Statistic & Value & $\mathrm{K}$ \\
\hline F-statistic & $8.310494^{*}$ & 5 \\
\hline \multicolumn{3}{|c|}{ Critical Value Bounds (@) } \\
\hline Significance & $\mathrm{I}(0)$ Bound & $\mathrm{I}(1)$ Bound \\
\hline $10 \%$ & 2.26 & $3.35^{* * *}$ \\
\hline $5 \%$ & 2.62 & $3.79^{* *}$ \\
\hline $2.5 \%$ & 2.96 & 4.18 \\
\hline $1 \%$ & 3.41 & $4.68^{*}$ \\
\hline
\end{tabular}

Source: Extracted from Researcher's Regression Analysis Output, 2016

Table 4.3(b) Model (II) LC -Bounds Test Results for Co-integration ARDL Bounds Test

Null Hypothesis: No Long-run Relationship Exist

\begin{tabular}{|c|c|c|}
\hline Test Statistic & Value & $\mathrm{K}$ \\
\hline F-statistic & $11.23002^{*}$ & 5 \\
\hline \multicolumn{2}{|c|}{ Critical Value Bounds (@) } \\
\hline Significance & $\mathrm{I}(0)$ Bound & $\mathrm{I}(1)$ Bound \\
\hline $10 \%$ & 2.26 & $3.35^{* * *}$ \\
\hline $5 \%$ & 2.62 & $3.79^{* *}$ \\
\hline $2.5 \%$ & 2.96 & 4.18 \\
\hline $1 \%$ & 3.41 & $4.68^{*}$ \\
\hline
\end{tabular}

Notes: $\mathrm{k}$ is the number of regressors in the ARDL model. *, **, ***

Indicates significance at 1\%,5\% and 10\% levels respectively.(@) Base on Pesaran, etal (2001).

Source: Extracted from Researcher's Regression Analysis Output, 2016

Based on the principles underlying of the ARDL bounds test approach to co-integration, the lower bound critical values (LCV) assume that the explanatory variables are integrated of order zero, or I(0), while the upper bound critical values (UCV) assume that the explanatory variables are integrated of order one, or I(1). Hence, if the computed F-statistic is less than the lower bound value, the null hypothesis is not rejected. On the other hand, if the computed F-statistic is greater than the upper bound values the null hypothesis is rejected. However, if the computed F-statistic falls between the lower and upper bound values, the results are inconclusive or uncertain. Results in Table 4.3(a) and 4.3(b) suggest that the application of the bounds F-test using ARDL modeling approach indicate the existence of a long run relationship between NWC and NOR, CNA, ROI, RFA and RM on one hand, between LC and NOR, CNA, ROI, RFA and RM on the other. The results show that the null hypothesis of no long run relationship is rejected at either $1 \%, 5 \%$ or $10 \%$ significance level. The Wald test (F-statistic) of 8.31 and 11.23 for both model (I) and (II) respectively, are greater than the upper critical bound values (UCV) of 3.79 and 3.79 for each model of $5 \%$ 
significance level Pesaran, etal (2001). Therefore, the null hypothesis of no co-integration cannot be accepted at 5\% significance level and hence, there is a co-integration relationship between the variables in the model.

\subsection{Post Estimation Analyses}

This section examines the usefulness, robustness and the reliability of the estimated models conducted using diagnostic test, stability test as well as chow test. Basic diagnostic tests such as serial correlation test, Ramsey RESET specification test, and Jacque-Bera normality test were conducted. The results are shown in table 4.6 below:

Table 4.4: Diagnostic Tests of the ARDL model

\begin{tabular}{|ll|l|l|l|l|}
\hline \multicolumn{2}{|c|}{ MODEL I (NWC) } & \multicolumn{2}{c|}{ MODEL II (LC) } \\
\hline \multicolumn{1}{|c|}{ Diagnostic Test } & F-statistic & P-Value & F-statistic & P-Value \\
\hline$>\quad$ B-G Serial Correlation LM Test & 0.20657 & 0.7242 & 0.2794 & 0.5304 \\
\hline$>$ Ramsey RESET Test & 0.65034 & 0.4900 & 0.373933 & 0.5841 \\
\hline
\end{tabular}

Source: Researcher's Regression Analysis Output, 2016

The serial correlation LM test from the B-G result shows that the hypothesis of zero autocorrelation in the residuals was not rejected for both models. This was because the probability values of 0.2066 and 0.5304 for model I and II are greater more than 5\% required to accept null hypothesis. Therefore, the Breusch-Godfrey serial correlation LM test did not reveal serial correlation problems for the models. Furthermore Ramesy RESET test also shows that both models are statistically significant, implying that the null hypothesis of model mis-specification cannot be rejected. Summarily, the diagnostic tests reveals that the residuals are serially uncorrelated, has a correct functional form and based on Breusch-Godfrey serial correlation LM test and Ramesy RESET Test respectively. It can therefore be deduced that the models has a satisfactory econometric properties, valid and can be used for policy making without re-specification.

\subsection{Summary and Conclusion}

From table 4.1 above, the coefficient of exogenous variables $(\mathrm{C}$ and CFS) are positive and (P, RFA and RM) are negative respectively in the model which implies that University Financial System is significantly affected and not affected by the combine effects of all the exogenous variables considered in the present study of the University system.

The table also shows that Core Financial System exacts a positive but has significant effect on University Financial System with a coefficient $\left(\beta_{1}\right)$ of 0.284611, Procurement exact a negative but non-significant effect on University System with a coefficient $\left(\beta_{2}\right)$ of -174.2060 , Research Financial Administration exacts a negative but non-significant effect on University 
Financial System with a coefficient $\left(\beta_{3}\right)$ of -0.003407 and Resource Management also has a negative but non-significant effect on University Financial System with a coefficient $\left(\beta_{4}\right)$ of -0.447661 .

The second partition of the table above shows the computed output of simple/dynamic regression which demonstrates R-square $=0.989475$, Adjusted R-square $=0.915798$, F-statistic $=13.42991$ respectively. The Rsquare shows that there is a positive relationship existing between the variables of interest (University Financial System, Core Financial System, Procurement, Research Financial Administration and Resource Management). The adjusted R-square of 0.915798 implies that 92 percent of the variation in University Financial System is explained by the independent variable captured in this study model. Meaning that 92 percent of changes in the University Financial System are attributed to the together effect of core financial system, procurement, research financial administration and resource management policies of the University and the remaining 30 percent of University Financial System is accounted for by other exogenous variables not included in this model for the present study.

In relation to the probability value of 0.207176 , this is higher than accepted level of 0.05 . This shows that the coefficient $\left(\beta_{4}\right)$ is statistically not significant in this model. It means that there is a positive but not significant relationship between University Financial System, Core Financial System, Procurement, Research Financial Administration and Resource Management. Hence we do not reject the null hypothesis that the variables do not exert a significant influence on University Financial System in Nigeria.

From this study and the scholarly reviews, it has been noted that forensic accounting is the application of a specialized knowledge and specific skills to stumble upon the evidence of economic transactions (Somoye and Osho, 2017). Today forensic accounting is a highly talked about topic all over the world and is the fastest growing area of accounting (Islam, Rahman, and Hossan, 2011).

The study has been able to establish that University Financial System in Nigeria is signal by the levels of Log of Oracle System Management (LOSM); Log of Reporting (LR); Log of Liquidity coverage (LC) and Log of net working capital (NWC). While University Financial System influence significantly the Forensic Accounting by effectively managing the individual component of forensic accounting viz: Core Financial System, Procurement, Research Financial Administration and Resource Management.

The study concluded that the combine effect of the explanatory variables on University Financial System in Nigeria (UFSN $=\alpha_{1}+\beta_{1}$ CFS + $\left.\beta_{2} \mathrm{P}+\beta_{3} \mathrm{RFA}+\beta_{4} \mathrm{RM}+\mu_{1}\right)$ is statistically and significantly in relation to effective management of Forensic Accounting components for the measurement of the University Financial System. This is evident from the F 
- ratio of 13.41991 and probability value of $0.284611 \mathrm{CFS}-174.2060 \mathrm{P}+-$ $\left.0.00347 \mathrm{RFA}+-0.447663 \mathrm{RM}+\mu_{1}\right)$.

As a result of the foregoing and based on the findings of this study, the following recommendations have been outline which will be useful to the stakeholders such as government, institutions, University regulators (National Universities Commission), supervisory bodies (International Federation of Accountants (IFAC and international Financial Reporting Standards IFRS)), public and scholars:

1. University management and the stakeholders viz Government, Universities regulators which include National Universities Commission (NUC) and supervisory bodies such as International Federation of Accountants (IFAC), International Financial Reporting Standards (IFRS), regulations and standards should utilize the findings of the study in taking decision with respect to efficient management of all the components of Forensic Accounting in order to grow their University and find this study useful in understanding how important is to standardize the University Financial System in Nigeria in order to bring about a sustained economic growth and economic development in the accounting standard globally.

2. In order to record proper or standard University Accounting System that is free from bias, Universities need adequate plan and effective management of items that cumulate in promoting the goodwill of the University system.

\section{References:}

1. Apostolou, B., Hassell, J. M. \& Webber, S. A. (2000). "Forensic expert classification of management fraud risk factors." Journal of Forensic Accounting, I, $181-192$.

2. Arokiasamy, L., \& Cristal - Lee, S. (2009). Forensic accounting: Public acceptance towards occurrence of fraud detection. International Journal of Business and Management, 144 - 160.

3. Balogna, J. \& Lindquist, R. (1995). Fraud auditing and forensic accounting

4. New York: Willey and Sons.

5. Business Advameg (2013). "Cash management". Inc. Retrieved 14 January 2013

6. Cannings M., \& O' Dwyer, B. (2001). 'Professional accounting bodies. Disciplinary procedures: Accountable, transparent and in the public interest? The European Accounting Review, 10 (4), 725 749. 
7. Chariri, A. (2009), "The relevance of forensic accounting in detecting financial frauds," Journal Organization Manajemen, 3 (2), $81-88$.

8. Coenen, T. L. (2005). "Forensic accounting". A new twist on bean counting",

Tracy@sequenceine.com

9. Crumbley, D. L. (2006). "Forensic accountants appearing in the literature". www.forensicaccounting.com.

10. Crumbley, D. L. (2003). What is forensic accounting? Forensic accounting: Older than you think. Journal of Forensic Accounting, 11(2), 181 - 202. www.edwardpub.com

11. GAO Financial Management Series, (2005). Core financial system requirements. Checklist for reviewing systems under the federal financial management improvement act. United States Government Accountability Office.

12. Georgas, P. G. \& Vallance, G. V. (1986). Cost management. Project Management Journal, 17(3), 47-54.

13. Gray, D. (2008). Forensic accounting and auditing: Compared and contrasted to traditional accounting and auditing. American Journal of Business Education, Fourth Quarter, 1 (2), 115 - 126.

14. Hao, X. (2010). Analysis of the necessity to develop the forensic accounting in China. International Journal of Business and Management, 5 (5), 185.

15. Howard, S. \& Sheetz, M. (2006). Forensic accounting and fraud investigation for non-experts. New Jersey: John Wiley and Sons Inc. New Jersey.

16. Islam J. Md., Rahman, H, Md. \& Hossan, T Mohd. (2011). Forensic accounting as a tool for detecting fraud and corruption: An empirical study in Bangladesh. ASA University Review, 5(2).

17. Joshi, M. S. (2003). Definition of forensic accounting. Retrieved from http:www.forensic Accounting on $15^{\text {th }}$ December 2014.

18. Larson, M. S. (1977). The rise of professionalism: A sociological analysis berkeley: University of California Press.

19. Manas, C. (2014). Problems and prospects of forensic accounting profession in India. International Journal of Informative and Futuristic Research: 2(1), 1-9.

20. Moran, Ed. (2017). Financial affairs. University of California. Scotts Valley CA 95066. https://financial.ucsc.edu/Pages/Ledger_Management.aspx

21. Pesaran, M.H., Shin, Y., and Smith, R.J. (2001). Bounds testing approaches to the

22. analysis of level relationships. Journal of Applied Econometrics, 16 (3), 289-326. 
23. Pollock, J. \& Amernic, J. (1981). "An examination of professional commitment in public accounting". Accounting, Organizations and Society, 6(4), $271-280$.

24. Okunbor, J. A \& Obaretin, O. (2010). Effectiveness of the application of forensic accounting service in Nigeria corporate organizations. AAU JMS, 1(1).

25. Osborne, L. (2015). Financial Search Blog. First Canadian Places, Toronto.

26. Ozkul, F. U. \& Pamukc, A. (2012). Fraud detection and forensic accounting, Istanbul, Turkey.

27. Small Business Notes (2013). "Cash management". Inc. Retrieved 14 January 2013

28. Somoye, R.O.C \& Osho, A.E. (2017). Forensic accounting on university financial system in Nigeria. Implication for sustainable development. Proceedings of the 1 International Conference on achieving sustainable development goals in Nigeria by the Year 2030, October 25-27, 2017.

29. Zysman, A. (2004). "Forensic accounting demystified". World investigators network standard practice for investigative and forensic accounting engagements, Canadian Institute of Chartered Accountant, Nov. 2006.

30. Zysman, A. (2001). "Forensic accounting demystified". Would investigators

31. network standard practice for investigation and forensic accounting engagement.

\section{Retrieved Statement}

32. ACCA, (2016). Accounting Coach, LLC.com

33. Accounting Dictionary (2016). Accounting tools. http://www.accountingtools.com/dictionary-inventory.

34. Accounting Dictionary (2016). Accounting Tools. http://www.accountingtools.com/noncurrent-asset

35. Accounting Dictionary (2016). Accounting tools. http://www.accountingtools.com/definition accounts-payable.

36. Accounting Tools (2017). https://www.accountingtools.com/articles/2017/5/5/accountspayable

37. Chattered institute of Procurement and Supply, (2016). Supply Management

38. https://www.cips.org/en/membership/why-join-cips/what-isprocurement-and-supply/ 
39. Management Reporting System, (2001). Web Science, E-Business Technologies. http://www.ecs.soton.ac.uk/research/projects/EBusiness\%20Technologies 